\title{
The Physiological Basis of Heterosis for Potassium Uptake of Hybrid Millet
}

\author{
Zihui Liu', Binhui Liu², Hongmei Zhang1, Guoliang Li', Yanmin Zhang1, Xiulin Guo ${ }^{1 *}$ \\ ${ }^{1}$ Institute of Genetics and Physiology, Hebei Academy of Agriculture and Forestry Sciences, Plant \\ Genetic Engineering Center of Hebei Province, Shijiazhuang, China \\ ${ }^{2}$ Institute of Dryland Farming, Hebei Academy of Agriculture and Forestry Sciences, Hengshui, China \\ Email: ${ }^{*}$ myhf2002@163.com
}

Received 27 April 2014; revised 26 May 2014; accepted 18 June 2014

Copyright (C) 2014 by authors and Scientific Research Publishing Inc.

This work is licensed under the Creative Commons Attribution International License (CC BY).

http://creativecommons.org/licenses/by/4.0/

(c) () Open Access

\begin{abstract}
Hybrid millet Zhang and its parental cultivars were studied for their potassium (K) uptake and accumulation characteristics and related physiological mechanisms. Hydroponic culture was performed with two K levels (i.e., high and low) set up. At high $\mathrm{K}$ level, hybrid millet showed heterobeltiosis in $\mathrm{K}$ accumulation and leaf $\mathrm{K}$ content, and it also had higher $\mathrm{H}^{+}$-ATPase activity, respiration rate, root oxidant activity and root $\mathrm{K}^{+}$influx rate than its parental cultivars. All these lay the physiological foundation of heterosis for potassium uptake of hybrid millet. At low $\mathrm{K}$ level, the hybrid millet had a lower $\mathrm{H}^{+}$-ATPase activity and a higher $\mathrm{K}$ efflux rate than its parental cultivars, thus heterobeltiosis in $K$ accumulation or leaf $K$ content was not observed. Therefore, high level $K$ fertilizer application is recommended for hybrid millet cultivation as it is favorable for hybrid millet to display heterosis in $\mathrm{K}$ uptake and $\mathrm{K}$ accumulation.
\end{abstract}

\section{Keywords}

Hybrid Millet, Potassium Uptake, Heterosis, Physiological Characteristics

\section{Introduction}

Utilization of heterosis is one of the important ways to increase yields. It has been widely validated in rice, maize, sorghum and other crops. Grain yield is the product of dry matter accumulation and harvest index (HI). High dry matter accumulation has been demonstrated in $\mathrm{F}_{1}$ hybrids and deemed as a main cause of heterosis in grain yield [1]-[5]. High dry matter accumulation was associated with the increased photosynthetic capacity which was demonstrated in such as Arabidopsis hybrids [6], super-hybrid rice [7] [8], maize hybrids [9]. On the other

\footnotetext{
${ }^{*}$ Corresponding author.

How to cite this paper: Liu, Z.H., Liu, B.H., Zhang, H.M., Li, G.L., Zhang, Y.M. and Guo, X.L. (2014) The Physiological Basis of Heterosis for Potassium Uptake of Hybrid Millet. American Journal of Plant Sciences, 5, 2006-2014.

http://dx.doi.org/10.4236/ajps.2014.513215
} 
hand, High dry matter accumulation must be associated with high nutrient uptake through roots. Therefore, understanding the characteristics of nutrient uptake of hybrids is quite important. Previous studies about heterosis of nutrient uptake in hybrids have found that: 1) The nitrogen, phosphorous, and potassium accumulating capacities of hybrids were greater than those of conventional cultivars [10] [11]; 2) Hybrids were more tolerant to nutrient deficiency [12] [13]. The above heterosis is believed to be due to changes in the morphological characters of roots or increase in physiological activities [14].

Foxtail millet [Setaria italica (L.) P. Beauv.] was the second largest cultivated millet species in the world, and was the popular food for China and many African countries. Even so, little attention was given to the study on the heterosis of foxtail millet. The hybrid millet was bred until 2000 [15], and there are few papers on hybrid millet as it was bred successfully only recently [16] [17]. The nutrient uptake characteristics of hybrid millet remained largely unknown. Results of our field study displayed that hybrid millet has a higher $\mathrm{K}$ accumulation capacity than nitrogen and phosphorus accumulation capacity. Yet, related mechanism was not clear. In this paper, physiological characteristics related to $\mathrm{K}$ uptake were investigated with hybrid millet Zhang 3 and its parental cultivars. The results from this study are expected to unveil physiological characteristics of $\mathrm{K}$ uptake and accumulation in hybrid millet and help agronomists to establish suitable culture practices for hybrid millet.

\section{Materials and Methods}

\subsection{Materials}

Hybrid millet Zhang 3 and its parental cultivars provided by the Zhangjiakou Academy of Agriculture Science were used as plant materials. Experiments were carried out in the Laboratory of Plant Physiology and Molecular Biology, Institute of Genetics and Physiology, Hebei Academy of Agriculture and Forestry Sciences, in 2012.

\subsection{Seedling Culture}

Plump seeds of similar sizes were selected and sown in vermiculite. When the seedlings grew to $3 \mathrm{~cm}$ high, they were taken out, fixed in cystosepiments with holes, and transferred to conical flasks containing $300 \mathrm{ml}$ of Hoagland nutrient solution ( $2.5 \mathrm{mM} \mathrm{Ca}\left(\mathrm{NO}_{3}\right)_{2}, 1 \mathrm{mM} \mathrm{MgSO}_{4}, 0.5 \mathrm{mM} \mathrm{NH}_{4} \mathrm{H}_{2} \mathrm{PO}_{4}, 0.2 \mu \mathrm{M} \mathrm{CuSO}_{4}, 1 \mu \mathrm{M} \mathrm{ZnSO} \mathrm{Z}_{4}, 0.1$

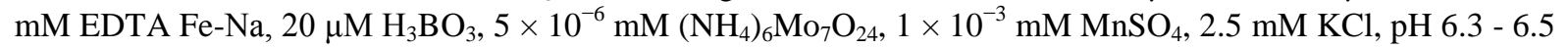
(adjusted with $1 \mathrm{M} \mathrm{NaOH}$ )). The flasks were wrapped with black plastic paper and put in a growth chamber. After two weeks, the seedlings were subjected to one of the two K level treatments: one was K-stress treatment with $0.02 \mathrm{mmol} \cdot \mathrm{L}^{-1} \mathrm{KCl}$ in the Hoagland solution, and the other was a high $\mathrm{K}$ level treatment with $2.5 \mathrm{mmol} \cdot \mathrm{L}^{-1}$ $\mathrm{KCl}$. To keep nutrient levels, solutions were refreshed every 3 days. The plants were grown in the growth chamber under fluorescent lights with $400 \mu \mathrm{mol} \cdot \mathrm{m}^{-2} \cdot \mathrm{s}^{-1}$ of light for $14 \mathrm{~h} \cdot \mathrm{d}^{-1}$. Daytime temperature was $26^{\circ} \mathrm{C}$, night-time temperature was $24^{\circ} \mathrm{C}$, and relative humidity was approximately $70 \%$. After three weeks, leaves, stems and roots were harvested and $\mathrm{K}$ content, $\mathrm{H}^{+}$-ATPase activity, root vigour, respiration rate, and root $\mathrm{K}^{+}$flux were determined.

\subsection{Measured Parameters and Methods}

\subsubsection{Leaf K Content and Plant K Accumulation}

Potassium content: potassium in the leaves was extracted with $1 \mathrm{~mol} \cdot \mathrm{L}^{-1} \mathrm{HCl}$ and measured with a flame spectrophotometer [18].

Total $\mathrm{K}$ in shoots $=$ leaf $\mathrm{K}$ content $\times$ leaf biomass + stem $\mathrm{K}$ content $\times$ stem biomass

\subsection{2. $\mathrm{H}^{+}$-ATPase Activity}

Plasma membrane (PM) vesicles were isolated from root microsomes using phase partitioning as described by Larsson [19] and modified by K1obus [20]. The hydrolytic activity of vanadate-sensitive ATPase was determined according to the modified procedure of Gallagher and Leonard [21] [22]. The reaction mixture contained $50 \mu \mathrm{g}$ of protein (plasma membrane), $33 \mathrm{mM}$ Tris-Mes (pH 7.5), $3 \mathrm{mM} \mathrm{ATP,} 2.5 \mathrm{mM} \mathrm{MgSO}$, $50 \mathrm{mM} \mathrm{KCl}, 1$ $\mathrm{mM} \mathrm{NaN}_{3}, 0.1 \mathrm{mM} \mathrm{Na}_{2} \mathrm{MoO}_{4}, 50 \mathrm{mM} \mathrm{NaNO}{ }_{3}, \pm 200 \mu \mathrm{M} \mathrm{Na}_{3} \mathrm{VO}_{4}$, and $0.02 \%$ Triton X-100. PM H $\mathrm{H}^{+}$-ATPase activity was expressed as the difference of that measured in the absence and in the presence of $\mathrm{Na}_{3} \mathrm{VO}_{4}$. The Pi released during the reaction was determined according to Ames [23] with $0.2 \%$ (w/v) sodium dodecyl sulphate in- 
cluded to prevent precipitation [24]. Protein was measured according to Bradford [25] in the presence of $0.02 \%$ Triton X-100 with bovine serum albumin as the standard.

\subsubsection{Root Activity}

Intact root activity (unit: $\mu \mathrm{g} \cdot \mathrm{g}^{-1} \cdot \mathrm{DW} \cdot \mathrm{h}^{-1}$ ) was measured by the $\alpha$-naphthylamine oxidation method [26].

\subsubsection{Root Respiration Rate}

Root respiration rate was measured as described by Zhao et al. [27]. Rinse the reactor with distilled water for three times and add in $2 \mathrm{~mL}$ distilled water. Rinse the stirrer and put it into the reactor. Take the roots out from the buffer solution, rinse for 2 - 3 times, dry with absorbent papers, quickly weigh about $0.05 \mathrm{~g}$, cut the roots into $2 \mathrm{~mm}$-long fragments, and put them into the reactor. Stamp the reactor, deaerate and start the measuring program. The temperature of the solution in the reactor was controlled at $25^{\circ} \mathrm{C}$ using a thermostatic bath. Stop the reaction after the reaction curve has arrived at a steady state for $10 \mathrm{~min}$ and choose a desired length from the curve for respiration rate calculation.

\subsubsection{Root K+ Flux}

Seedlings were taken from the nutrient solution to $0.2 \mathrm{mM} \mathrm{CaSO}_{4}$ solution for $24 \mathrm{~h}$ of $\mathrm{K}$ starvation. Roots were excised at $5 \mathrm{~cm}$ from the root tips and transferred to measuring solutions $(0.1 \mathrm{mM} \mathrm{CaCl}, 0.1 \mathrm{mM} \mathrm{MgCl} 2,0.3$ $\mathrm{mM}$ MES, pH 6.0) with high $\mathrm{K}$ level $(2.5 \mathrm{mM} \mathrm{KCl})$ or low $\mathrm{K}$ level $(0.02 \mathrm{mM} \mathrm{KCl})$. After $20 \mathrm{~min}$ for equilibrium, the roots were then transferred to a small plastic dish $(3 \mathrm{~cm}$ in diameter) containing $2-3 \mathrm{~mL}$ of fresh measuring solution in the measuring chamber and fixed for measurement. The microelectrode was vibrated in the measuring solution between two positions, $5 \mu \mathrm{m}$ and $35 \mu \mathrm{m}$ from the root surface, respectively along an axis perpendicular to the root. Prior to flux measurements, the ion-selective electrodes were calibrated using $\mathrm{KCl}$ solutions with concentrations of 0.01 and $5 \mathrm{mM}$. The net fluxes of $\mathrm{K}^{+}$at the meristematic zone were measured. Five to seven roots were taken from each treatment, and each root was measured once. All measurements of net $\mathrm{K}^{+}$fluxes were carried out at Xuyue Science and Technology Co., Ltd. (Beijing, China). The principle of this method and the instrument used are detailed in Sun et al. [28].

\subsubsection{Kinetics of Root K Uptake}

The ion depletion technique was employed in the root K uptake kinetics experiment. After cultured in Hoagland nutrient solution with $2.5 \mathrm{mM} \mathrm{K}$ for 5 weeks, seedlings of similar sizes were selected from each cultivar and put in starvation solutions $\left(0.2 \mathrm{mmol} \cdot \mathrm{L}^{-1} \mathrm{CaSO}_{4}\right)$ for $24 \mathrm{~h}$. The roots were washed with $0.2 \mathrm{mmol} \cdot \mathrm{L}^{-1} \mathrm{CaSO}_{4}$ for 3 times, dried and cultured in $100 \mathrm{~mL}$ bathing solution which contained $0.244 \mathrm{mmol} \cdot \mathrm{L}^{-1} \mathrm{KCl}$ and $0.2 \mathrm{mmol} \cdot \mathrm{L}^{-1}$ $\mathrm{CaSO}_{4}$. Samples were taken every one hour until $\mathrm{K}^{+}$concentration in the bathing solution stabilized. For each sampling, $1 \mathrm{~mL}$ solution was taken, and $1 \mathrm{~mL}$ solution of the same concentration was added for compensation [29]. When the experiment ended, the roots were cut, their fresh weights were obtained. The depletion experiment was carried out in triplicate. The kinetic parameters were obtained using the model described by Jiang et al. [30]: $Y=a+b x+c x^{2}$, where $x$ is the uptake time and $Y$ is $\mathrm{K}^{+}$concentration at a certain time. Then kinetic parameters $\mathrm{K}_{\mathrm{m}}, \mathrm{C}_{\min }$ and $\mathrm{V}_{\max }$ can be calculated using the following equations:

$\mathrm{V}_{\max }=b \times$ volume of bathing solution $(\mathrm{mL}) \div$ root fresh weight $(\mathrm{g}), \mathrm{K}_{\mathrm{m}}=\left(a-3 b^{2}\right) / 16 c$, and

$\mathrm{C}_{\min }=\left(a-b^{2}\right) / 4 c$, where the absolute values of $a, b$, and $c$ are used, $\mathrm{K}_{\mathrm{m}}$ is the affinity constant of roots for ions, $\mathrm{C}_{\min }$ is the minimum critical concentration or the external $\mathrm{K}^{+}$concentration at zero net $\mathrm{K}^{+}$uptake, and $\mathrm{V}_{\max }$ is the maximum $\mathrm{K}^{+}$uptake rate.

\subsection{Statistics}

Microsoft excel 2003 was used for data processing and figure generating. Analysis of variance was done using the SPSS software package.

\section{Results}

\subsection{K Accumulation, K Content and Shoot Biomass}

Hybrid millet accumulated significantly more $\mathrm{K}$ than its parental cultivars, showing heterobeltiosis at high $\mathrm{K}$ 
level. Yet, no heterobeltiosis was observed at low K level as there was no significant difference in K accumulation between hybrid millet and its parents. Moreover, both hybrid millet and its parental cultivars accumulated more $\mathrm{K}$ when grown at high $\mathrm{K}$ level than at low K level (Figure 1(a)).

Similarly, leaf K content was significantly higher when hybrid millet was grown at high $\mathrm{K}$ level than at low K level, which was also found by previous studies with hydroponic culture [31] or soil culture [32]. Cultured at high $\mathrm{K}$ level, the leaf $\mathrm{K}$ content of hybrid millet was close to that of its mother cultivar but significantly higher than that of its father cultivar. At low K level, the leaf $\mathrm{K}$ content in hybrid millet was significantly lower than those in its parents (Figure 1(b)).

Similar to K accumulation and leaf K content, hybrid millets showed high heterosis in shoot biomass at high $\mathrm{K}$ level. Similarly, heterosis in shoot biomass was depressed at low K level (Figure 1(c)).

\section{2. $\mathrm{H}^{+}$-ATPase Activity, Root Vigour and Respiration Rate}

$\mathrm{H}^{+}$-ATPase activity in root plasma membrane of hybrid millet was significantly higher than those of its parental cultivars at high $\mathrm{K}$ level, while at low $\mathrm{K}$ level, $\mathrm{H}^{+}$-ATPase activity in hybrid millet decreased markedly, increased significantly in its mother cultivar and slightly in its father cultivar. This indicated that environmental $\mathrm{K}$ level can influence $\mathrm{H}^{+}$-ATPase activity in root plasma membrane, and how $\mathrm{H}^{+}$-ATPase activity changes is cultivar-dependent. Root $\mathrm{H}^{+}$-ATPase activity in hybrid millet clearly showed heterobeltiosis under high $\mathrm{K}$ conditions and no heterobeltiosis under low $\mathrm{K}$ conditions, indicating that good nutrient conditions are advantageous in activating $\mathrm{H}^{+}$-ATPase in hybrid millet (Figure 2(a)).

The rate of $\alpha$-naphthylamine oxidation, which is mediated by peroxidase [33] and correlates with respiration rate of the roots [34], was in the order of hybrid millet > mother cultivar > father cultivar for both $\mathrm{K}$ levels, and was significantly higher in the former than in the latter two. Therefore, hybrid millet showed high heterosis in root activity under both K level conditions (Figure 2(b)).

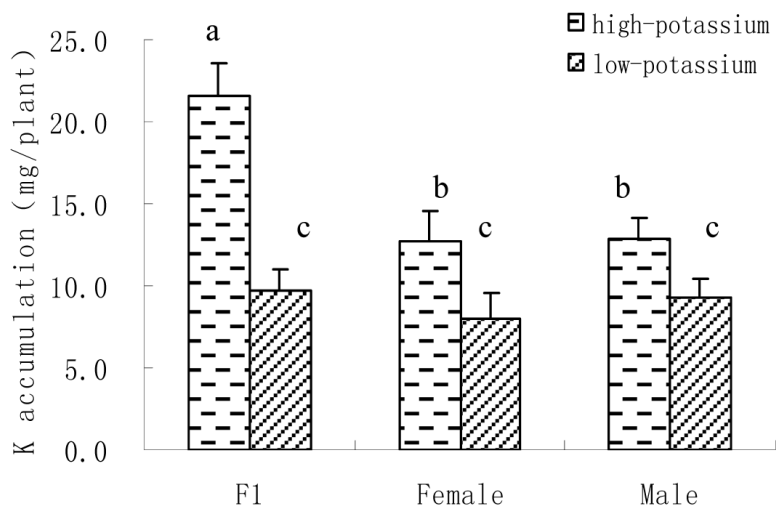

(a)

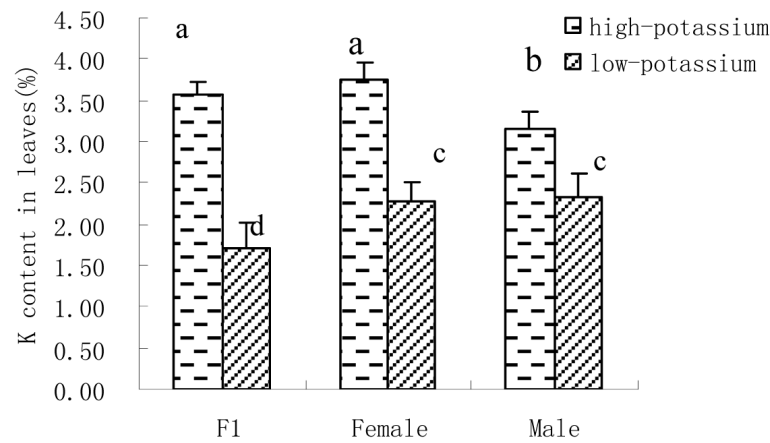

(b)

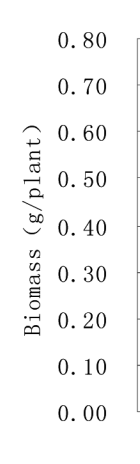

0.00 $\square$ high-potassium
$\square$ low-potassium

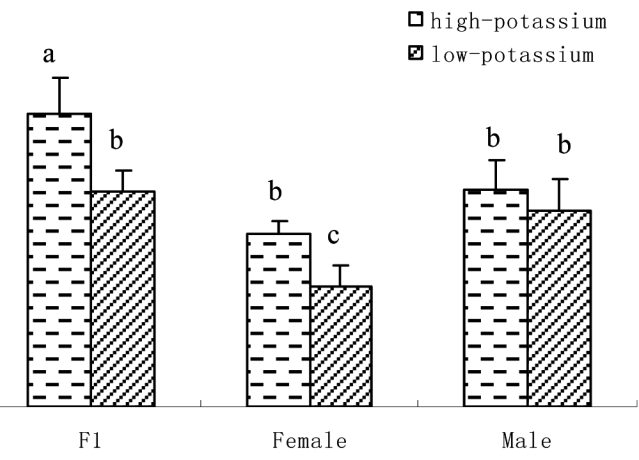

(c)

Figure 1. Plant K accumulation (a); leaf K content (b) and shoot biomass (c) in hybrid millet and its parental cultivars at high and low K level (Different letters on top of the columns denote significant difference at $P<0.05$, applicable to the following figures). 


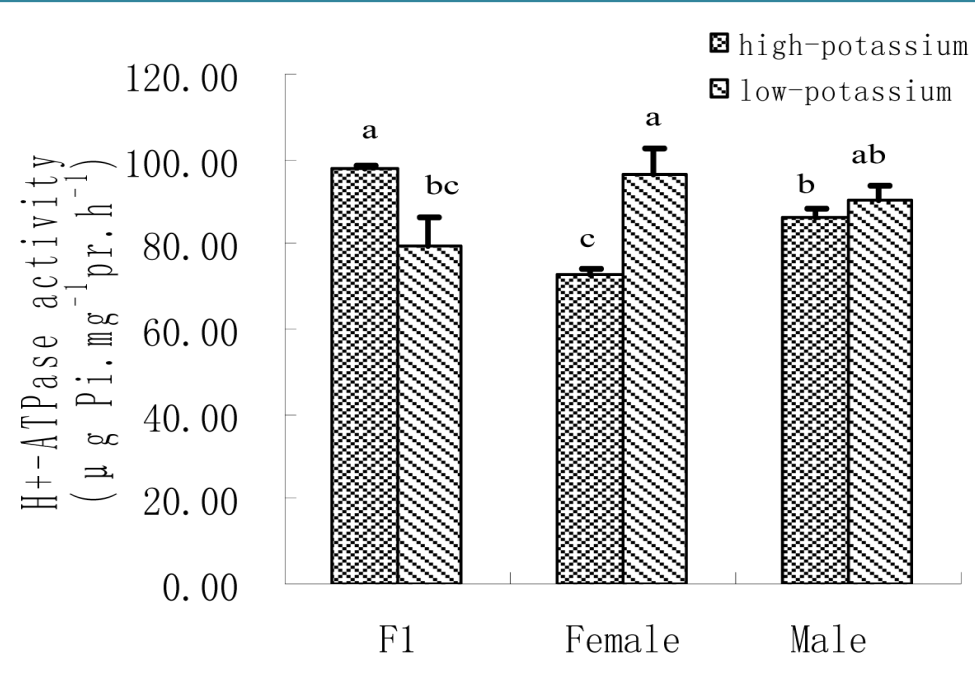

(a)

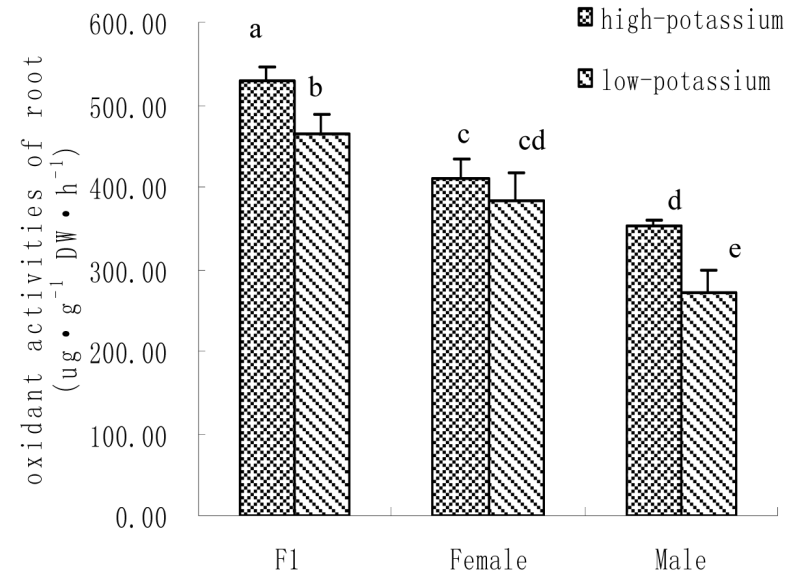

(b)

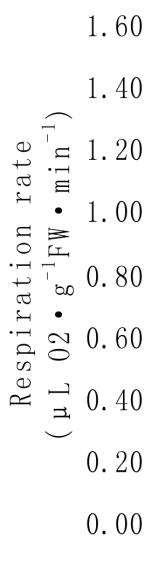

0.00

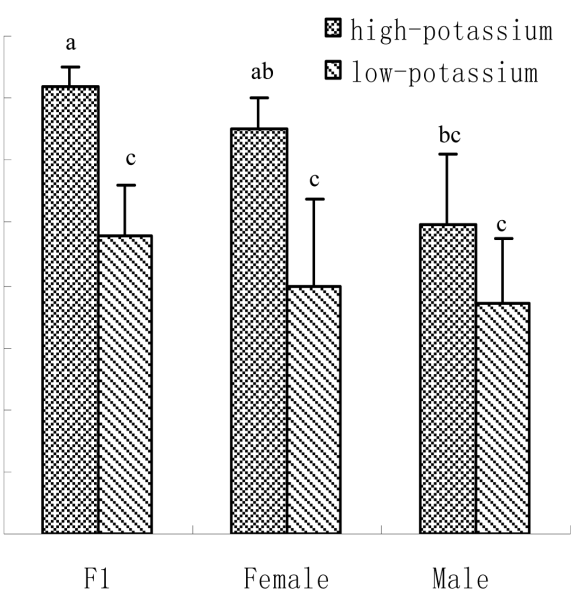

(c)

Figure 2. Root plasma membrane $\mathrm{H}^{+}$-ATPase activity (a); root vigour (b) and respiration rate (c) in hybrid millet Zhang and its parental cultivars at high and low K level.

It can be seen from Figure 2(c) that there was no significant difference in root respiration rate between hybrid millet Zhang and its parental cultivars at low $\mathrm{K}$ level, while root respiration rate in hybrid millet was significantly higher than that in its father cultivar and was close to that in its mother cultivar at high $\mathrm{K}$ level. Root respiration rate in hybrid millet displayed heterobeltiosis only at high K level (Figure 2(c)).

\section{3. $\mathrm{K}^{+}$Flux}

Root $\mathrm{K}^{+}$flux rate was measured at the meristematic zone $600 \mu \mathrm{m}$ above the root cap. The results revealed that under low $\mathrm{K}$ conditions, oscillating $\mathrm{K}^{+}$efflux was observed in the hybrid millet and its parental cultivars. The efflux rate in the hybrid millet was about $75 \mathrm{pmol} \mathrm{cm}{ }^{-2} \cdot \mathrm{s}^{-1}, 4$ and 2 times those of its mother and father cultivars, respectively. Differences in efflux rate between cultivars were significant $(P<0.05)$ (Figure 3(a)). At high $\mathrm{K}$ level, both influx and efflux of $\mathrm{K}$ were observed, but the mean value of efflux was higher than that of influx for the three cultivars. There were no significant differences in $\mathrm{K}$ efflux rate between hybrid millet and its parental cultivars, while the $\mathrm{K}$ influx rates of hybrid millet and its mother cultivar were significantly higher than that of its father cultivar (Figure 3(b)).

\subsection{Root $\mathrm{K}^{+}$Uptake Kinetics}

As shown in Table 1, there were differences in $\mathrm{K}^{+}$uptake kinetics between hybrid millet and its parental culti- 


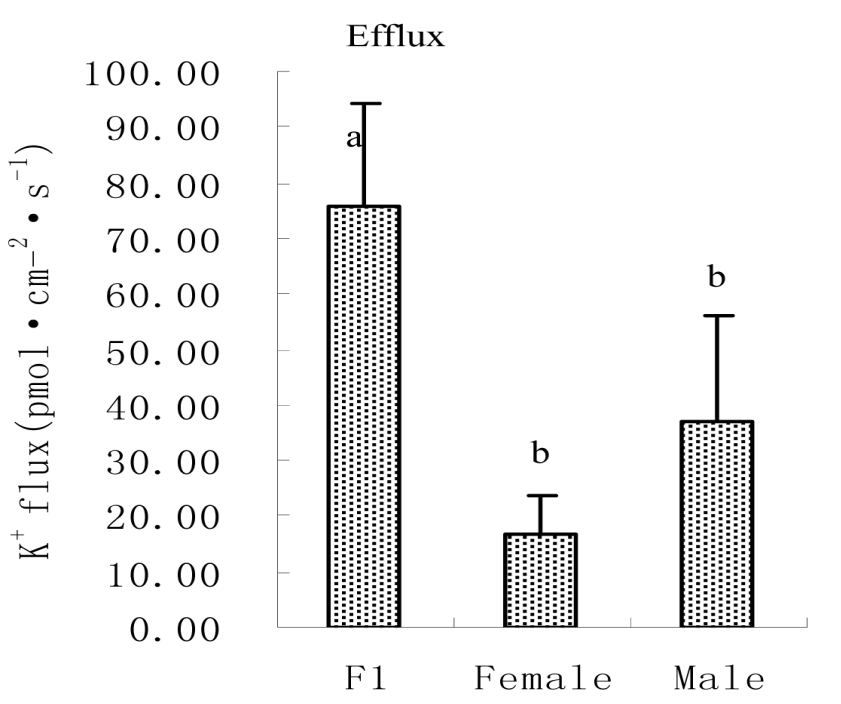

(a)

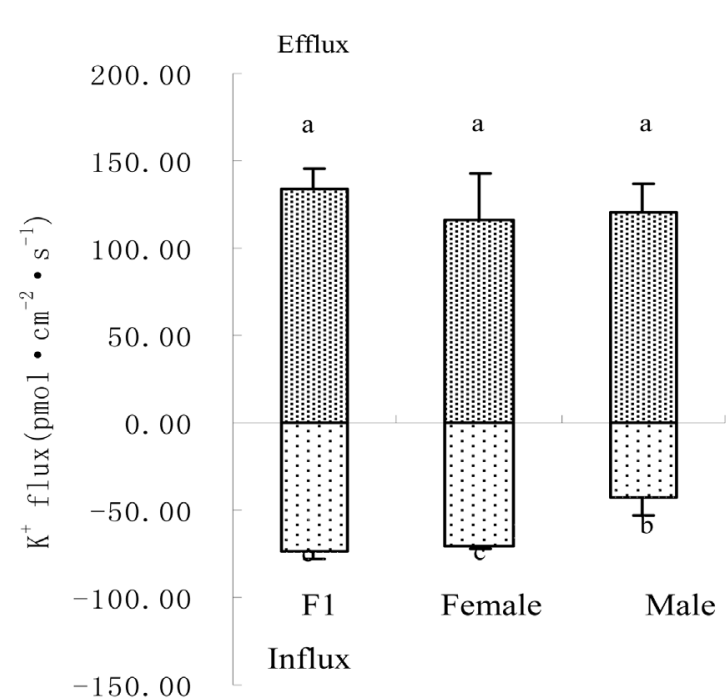

(b)

Figure 3. Root $\mathrm{K}^{+}$flux rate in hybrid millet and its parental cultivars at low (a) and high (b) K level.

Table 1. Root K uptake kinetic parameters for hybrid millet Zhang and its parental cultivars.

\begin{tabular}{cccc} 
& $\begin{array}{c}\mathrm{V}_{\max } \\
\left(\mathrm{mg} \cdot \mathrm{g}^{-1} \mathrm{FW} \cdot \mathrm{h}^{-1}\right)\end{array}$ & $\begin{array}{c}\mathrm{K}_{\mathrm{m}} \\
\left(\mathrm{mg} \cdot \mathrm{L}^{-1}\right)\end{array}$ & $\begin{array}{c}\mathrm{C}_{\mathrm{min}} \\
\left(\mathrm{mg} \cdot \mathrm{L}^{-1}\right)\end{array}$ \\
\hline $\mathrm{F}_{1}$ & $80.09 \pm 5.29 \mathrm{a}$ & $1.60 \pm 0.27 \mathrm{~b}$ & $0.45 \pm 0.33 \mathrm{c}$ \\
Female & $67.95 \pm 6.62 \mathrm{~b}$ & $2.15 \pm 0.42 \mathrm{~b}$ & $2.21 \pm 0.44 \mathrm{~b}$ \\
Male & $40.67 \pm 4.90 \mathrm{c}$ & $3.77 \pm 0.14 \mathrm{a}$ & $3.33 \pm 0.19 \mathrm{a}$ \\
\hline
\end{tabular}

Note: Different letters in the same column denote significant $(P<0.05)$ differences between cultivars.

vars. The hybrid millet had a significantly higher $\mathrm{V}_{\max }$ than its parental cultivars, i.e., 1.18 and 1.97 times that of its father and mother cultivars, respectively. The $\mathrm{K}_{\mathrm{m}}$ and $\mathrm{C}_{\mathrm{min}}$ for hybrid millet were significantly lower than those for its parental cultivars. It is generally believed that high $\mathrm{V}_{\max }$, low $\mathrm{K}_{\mathrm{m}}$, and $\mathrm{C}_{\min }$ denote an excellent potassium uptake capacity at potassium deficiency. The kinetic parameters strongly confirmed that the roots of the hybrid millet had a high potential in high efficient K uptake.

\section{Discussion}

Previous studies have demonstrated that hybrids were more tolerant to mineral nutrient deficiency. The capacity of tolerance was mainly showed by high biomass or high nutrient accumulation in hybrids. High nutrient accumulation must be accompanied by a capacity of nutrient acquisition when hybrids were grown in nutrient-poor soils [35]. However, the hybrid was always not like this case. There were reports that $F_{1}$ hybrids just showed heterosis in dry matter accumulation, but their growth was very limited with low nutrient concentrations in tissues [36] [37]. Even, Gouis [38] also founded that heterosis for yield and biomass was lower when the crops were grown without nitrogen. Thus, hybrids may require highly fertile soils or intensive fertilizer application when soil fertility is low. Similarly, Liu et al. also found that K demand of hybrid rice was about 1/5 higher than that of conventional rice [39]. In our study, leaf K content of hybrid millet was significantly lower than those of its parental cultivars, though shoot biomass of hybrid millet was higher than those of its parental cultivars when they were grown at low $\mathrm{K}$ level. In contrast, both leaf $\mathrm{K}$ content and plant $\mathrm{K}$ accumulation in hybrid millet grown in solution with high $\mathrm{K}$ displayed high heterosis. These suggest that hybrid millet can tolerant potassium deficiency, but sufficient $\mathrm{K}$ supply was rather favorable for heterosis in potassium uptake and accumulation.

Though the expression of heterosis of mineral nutrient accumulation in hybrid millet was affected by environments, it was firstly determined by their morphological and physiological characteristics. For example, the heterosis of phosphate acquisition in hybrid Arabidopsis thaliana was due to its long root hair trait inherited 
from its mother and its long root trait inherited from its father [40]. Masahiko [41] argued that the high nutrient uptake of $F_{1}$ rice hybrid was not dependent on its higher weight, but on its better physiological traits. In this study, the $V_{\max }$ value was high and $\mathrm{K}_{\mathrm{m}}$ value was low for the hybrid millet, which was in accordance with root uptake kinetic features of high $\mathrm{K}$ uptake crops pointed out by Graham et al. [42]. These parameters indicated that the hybrid millet has a high K uptake capacity. Due to that the K uptake process was affected by physiological activities, the manifest of $\mathrm{K}$ uptake depended on the growth vigour. In this study, the hybrid millet displayed higher growth vigor only when they were grown at high $\mathrm{K}^{+}$level. The rate of $\alpha$-naphthylamine oxidation and the respiration rate of roots were greater in hybrid millets than those in its parents. Respiration can produce energy for all life activities. This means that respiration can bring more ATP for $\mathrm{H}^{+}$-ATPase and then raise its activity in hybrid millet. $\mathrm{H}^{+}$-ATPase provides the driving force for secondary $\mathrm{K}^{+}$-transport carriers and/or channels [43]. As a result, the heterosis of $\mathrm{K}$ uptake, which was shown by high $\mathrm{K}$ content and accumulation in the hybrid millet, was achieved when they were grown at high $\mathrm{K}^{+}$level. But, the rate of $\mathrm{H}^{+}$-ATPase activities and the respiration rate of roots were not great in hybrid millets compared with those in its parents at the low K level. Therefore, the heterosis of leaf $\mathrm{K}$ content and $\mathrm{K}$ accumulation were not observed. This suggested that the growth vigour of hybrid millet was repressed at low K level. The research from Ni [44] showed that the higher growth vigor in hybrids and allopolyploids were from the altered circadian rhythms. So, it was very worth thinking whether or not the circadian rhythms of the hybrids were regulated by the potassium in leaves.

\section{Conclusion}

In a word, high K supply can activate the growth vigour in hybrid millet, which is favorable for the heterosis in potassium accumulation to show. Therefore, high level of $\mathrm{K}$ fertilizer application is recommended for hybrid millet cultivation.

\section{Acknowledgments}

The study was financially supported by the National Science and Technology Supporting Plan (2011BAD06B00) and the Key Basic Research Projects of the Basic Research for Application Plan of Hebei Province (11965517D).

\section{References}

[1] Blanco, L.C., Casal, C., Akita, S. and Virmani, S.S. (1990) Biomass, Grain Yield, and Harvest Index of F 1 Rice Hybrids and Inbreds. International Rice Research Newsletter, 15, 9-10.

[2] Yamauchi, M. (1994) Physiological Bases of Higher Yield Potential in F $F_{1}$ Hybrids. In: Virmani, S.S., Ed., Hybrid Rice Technology: New Developments and Future Prospects, International Rice Research Institute, Los Banos, 71-80.

[3] Rhonda, C.M., Törjék, O., Martina, B. and Thomas, A. (2004) Heterosis of Biomass Production in Arabidopsis: Establishment during Early Development. Plant Physiology, 134, 1813-1823. http://dx.doi.org/10.1104/pp.103.033001

[4] Kindred, D.R. and Gooding, M.J. (2005) Heterosis for Yield and Its Physiological Determinants in Wheat. Euphytica, 142, 149-159. http://dx.doi.org/10.1007/s10681-005-1250-y

[5] Kenneth, P.V. and Rob, B.M. (2008) Heterosis in Switchgrass: Biomass Yield in Swards. Crop Science, 48, $2159-2164$. http://dx.doi.org/10.2135/cropsci2008.02.0117

[6] Ryo, F., Jennifer, M.T. and Sachiko, S. (2012) Heterosis of Arabidopsis Hybrids between $\mathrm{C}_{24}$ and $\mathrm{C}_{01}$ Is Associated with Increased Photosynthesis Capacity. Proceedings of the National Academy of Sciences of the United States of America, 109, 7109-7114. http://dx.doi.org/10.1073/pnas.1204464109

[7] Wang, Q., Zhang, Q.D., Jiang, G.M., Lu, C.M., Kuang, T.Y., Wu, S., LI, C.Q. and Jiao, D.M. (2000) Photosynthetic Characteristics of Two Super High-Yield Hybrid Rice. Acta Botanica Sinica, 42, 1285-1288.

[8] Song, G.S., Zhai, H.L., Peng, Y.G., Zhang, L. and Wei, G. (2010) Comparative Transcriptional Profiling and Preliminary Study on Heterosis Mechanism of Super-Hybrid Rice. Molecular Plant, 3, 1012-1025. http://dx.doi.org/10.1093/mp/ssq046

[9] Tollenaar, M., Ahmadzadeh, A. and LeeE, A. (2004) Physiological Basis of Heterosis for Grain Yield in Maize. Crop Science, 44, 2086-2094. http://dx.doi.org/10.2135/cropsci2004.2086

[10] Fan, Q.J., Niu, Y.Z., Ni, S. and Yuan, J.C. (1997) Apreliminary Study on the Content and Absorption of Nitrogen, Phosphorus, Potassium of Several Varieties of Oil Seed Rape. Journal of Sichuan Agricultural University, 15, 205-210.

[11] Zhao, Z.H., Xu, Y.S. and Zhu, X.H. (2000) The Ways and Prospects of Heterotic Utilization of Foxtail Millet. Journal 
of Zhangjiakou Agricultural College, 1, 1-2.

[12] Seshadri, K. (1981) Differences in Fe-Stress Response in Sorghum Hybrids and Their Parental Lines: Evidence for Heterosis, 103, 285-290.

[13] Tian, X.L., Wang, G.W., Yang, F.Q., Yang, P.Z., Duan, L.S. and Li, Z.H. (2008) Differences in Tolerance to Low-Potas-sium Supply among Different Types of Cultivars in Cotton (Gossypium hirsutum L.). Acta Agronomica Sinica, 34, 1770-1780. http://dx.doi.org/10.3724/SP.J.1006.2008.01770

[14] Li, B.X., Guo, C.J., Wang, B., Xiao, K. and Li, Y.M. (2006) Acquisition and Utilization Characteristics of Phosphorus in Hybrid $F_{1}$ and Parents with Different P Efficiencies under Phosphorus Deficient Condition. Acta Agronomica Sinica, 32, 267-272.

[15] Zhao, W.C., Gao, X. and Yu, C.W. (2004) Heterosis for Tissue Nitrogen Accumulation and Content in Hybrid Wheat. Journal of Triticeae Crops, 24, 43-47.

[16] Liu, Z.H., Zhang, H.M., Zhang, Y.M., Li, G.L. and Guo, X.L. (2012) Photosynthetic Characteristics of Hybrid Millet at Grain Filling Stage. Acta Agriculturae Boreali-Occidentalis Sinica, 11, 60-64.

[17] Guo, X.L., Liu, Z.H., Wang, Y., Zhang, H.M., Zhang, Y.M., Li, H.C. and Zhao, Z.H. (2012) Studies on Isozymes of $\mathrm{MDH}$ and POD of Hybrid Millet Zhang in Different Growing Stages. Acta Botanica Boreali-Occidentalia Sinica, 32, 1768-1773.

[18] Nanjing Agricultural University (1994) Soil Agro-Chemistry Analysis. China Agricultural Press, Beijing, $218-219$.

[19] Larsson, C. (1985) Modern Methods of Plant Analysis. Cell Components, 1, 85-104.

[20] Klobus, G. (1995) The Role of Plasma Membrane-Bound Activities in Nitrate Transport into Sealed Plasma Membrane Vesicles from Cucumis sativus L. Roots. Structure and Function of Roots, 58, 133-140.

[21] Gallagher, S.R. and Leonard, R.T. (1982) Effect of Vanadate, Molybdate and Azide on Membrane-Associated Atpase and Soluble Phosphatase Activities of Corn Roots. Plant Physiology, 70, 1335-1340. http://dx.doi.org/10.1104/pp.70.5.1335

[22] Sze, H. (1985) $\mathrm{H}^{+}$-Translocating Atpase: Advances Using Membrane Vesicles. Annual Review of Plant Physiology, 36, 175-208. http://dx.doi.org/10.1146/annurev.pp.36.060185.001135

[23] Ames, B.N. (1966) Assay of Inorganic Phosphate, Total Phosphate and Phosphatases. Methods in Enzymology, 8, 115118. Http://Dx.Doi.Org/10.1016/0076-6879(66)08014-5

[24] Dulley, J.R. (1975) Determination of Inorganic Phosphate in the Presence of Detergents or Protein. Analytical Biochemistry, 67, 91-96. http://dx.doi.org/10.1016/0003-2697(75)90275-4

[25] Bradford, M.M. (1976) A Rapid and Sensitive Method for the Quantification of Microgram Quantities of Protein Utilizing the Principles of Protein-Dye Binding. Analytical Biochemistry, 72, 248-254. http://dx.doi.org/10.1016/0003-2697(76)90527-3

[26] Zhang, Z.L. (1992) The Guidance of Plant Physiological Experiment. Higher Education Press, Beijing, 61-62.

[27] Zhao, S.J., Liu, H.S. and Dong, X.C. (1998) The Guidance of Plant Physiological Experiment. China Agricultural Science and Technology Press, Beijing, 149-161.

[28] Sun, J., Chen, S.L., Dai, X.L., Zhou, X.Y., Lu, C.F., Zheng, X.J., Hu, Z.M., Zhang, Z.K., Song, J. and Xu, Y. (2009) $\mathrm{NaCl}$-Induced Alternations of Cellular and Tissue Ion Fluxes in Roots of Salt-Resistant and Salt-Sensitive Poplar Species. Plant Physiology, 149, 1141-1153. http://dx.doi.org/10.1104/pp.108.129494

[29] Classen, N. and Barber, S.A. (1974) A Method for Characterizing the Relation between Nutrient Concentration and Flux into Roots of Intact Plants. Plant Physiology, 54, 564-568. http://dx.doi.org/10.1104/pp.54.4.564

[30] Jiang, T.H., Zheng, S.J., Shi, J.Q., Hu, A.T., Shi, R.H. and Xu, W. (1995) Several Considerations in Kinetic Research on Nutrients Uptake by Plants. Plant Nutrition and Fertilizer Sciences, 1, 11-17.

[31] Zheng, X.B. and Cao, Y.P. (2000) Circulation, Accumulation and Distribution of Potassium in Flue-Cured Tobacco with Different Potassium Levels. Plant Nutrition and Fertilizer Science, 6, 166-172.

[32] Chen, J.Y. (1999) Technological Ways of Improving Potassium Content in Flue-Cured Tobacco Leaf. Chinese Tabacco Science, 4, 1-4.

[33] Matsunaka, S. (1960) Studies on the Respiratory Enzyme System of Plants. I Enzymatic Oxidation of A-Naphthylamine in Rice Plant Root. The Journal of Biochemistry, 47, 820-829.

[34] Yamada, N. and Nakamura, H. (1961) Diagnosis of Rice Root Activity with A-Naphthylamine. Agriculture and Horticulture, 36, 1983-1985.

[35] Shi, Q.H., Li, M.Y. and Tu, Q.H. (2002) Studies on Efficiency of N Nutrition and Physiological Factors in Roots of Hybrid Rice. Hybrid Rice, 17, 45-48.

[36] Kawano, K., Kurosawa, K. and Takahashi, M. (1969) Heterosis in Vegetative Growth of the Rice Plant: Genetical Stu- 
dies on Rice Plant. Japanese Journal of Breeding, 19, 335-342. http://dx.doi.org/10.1270/jsbbs1951.19.335

[37] Suzuki, Y. and Morooka, M. (1986) Nitrogen Absorption of $F_{1}$ Rice Hybrids. Japan Journal Soil Science. Plant Nutrition, 57, 149-154.

[38] Gouis, L., Beghin, J.D. and Heumez, E. (2002) Diallel Analysis of Winter Wheat at Two Nitrogen Levels. Crop Science, 42, 1129-1134. http://dx.doi.org/10.2135/cropsci2002.1129

[39] Liu, G.D. and Liu, G.L. (2002) Screening Hybrid Combinations of Indica Rice for K-Efficient Genotypes. Scientia Agricultura Sinica, 35, 1044-1048.

[40] Narang, R.A. and Altmann, T. (2001) Phosphate Acquisition Heterosis in Arabidopsis thaliana: A Morphological and Physiological Analysis. Plant and Soil, 234, 91-97. http://dx.doi.org/10.1023/A:1010545101345

[41] Masahiko, I. and Masahiko, N. (1990) Heterosis for Nutrient Uptake in F 1 Rice Hybrid-Seedlings. Japanese Journal of Crop Science, 59, 140-145. http://dx.doi.org/10.1626/jcs.59.140

[42] Graham, R.D. (1984) Breeding for Nutritional Characteristic in Cereals. Advanced Plant Nutrition, 1, 57-107.

[43] Inmaculada, G., Francisco, E., Alvarez-Tinaut, M.C. and Miguel, A. (1998) Net Simultaneous Hydrogen and Potassium Ion Flux Kinetics Insterile Aeroponic Sunflower Seedling Roots: Effects of Potassium Ion Supply, Valinomycin, and Dicyclohexylcarbodiimide. Journal Plant Nutrition, 21, 115-137. http://dx.doi.org/10.1080/01904169809365387

[44] Ni, Z.F., Kim, E.D., Ha, M., Lackey, E., Liu, J. and Zhang, Y. (2009) Altered Circadian Rhythms Regulate Growth Vigour in Hybrids and Allopolyploids. Nature, 457, 327-334. http://dx.doi.org/10.1038/nature07523 
Scientific Research Publishing (SCIRP) is one of the largest Open Access journal publishers. It is currently publishing more than 200 open access, online, peer-reviewed journals covering a wide range of academic disciplines. SCIRP serves the worldwide academic communities and contributes to the progress and application of science with its publication.

Other selected journals from SCIRP are listed as below. Submit your manuscript to us via either submit@scirp.org or Online Submission Portal.
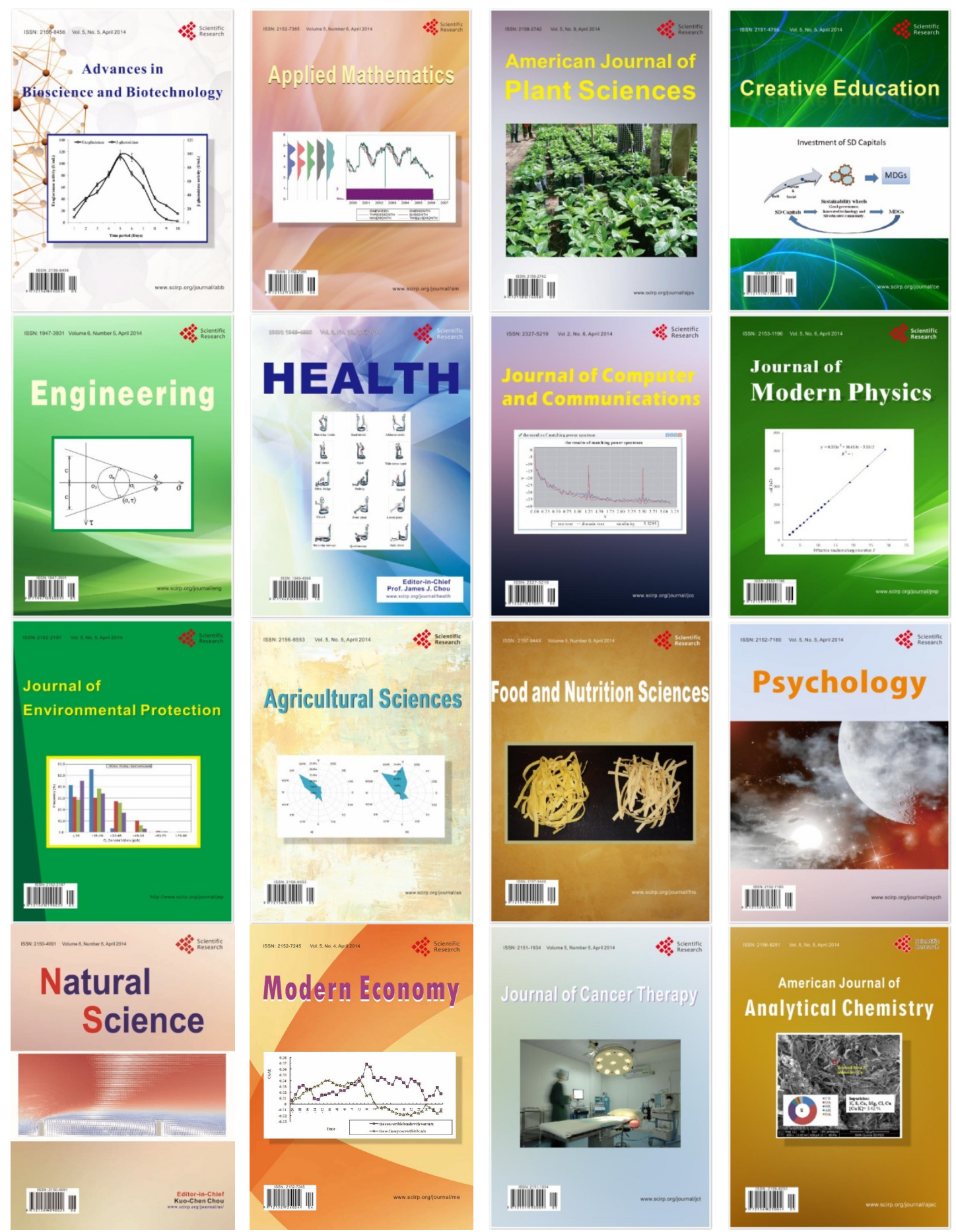